\title{
A Novel Neutral Organic Electron Donor with Record Half-Wave Potential
}

\author{
Hardeep S. Farwaha ${ }^{\mathrm{a}}$, Goetz Bucher ${ }^{\mathrm{b}}$ and John A. Murphy ${ }^{\mathrm{a} *}$ \\ Received (in $X X X, X X X$ ) Xth $X X X X X X X X X 20 X X$, Accepted $X$ th $X X X X X X X X X 20 X X$ \\ ${ }_{5}$ DOI: 10.1039/b000000x
}

Tricyclic donor $\mathbf{2 6}$ has been prepared and is the most reducing neutral ground-state organic molecule known, with an oxidation potential $260 \mathrm{mV}$ more negative than the previous record. Cyclic voltammetry shows that a 2-electron reversible redox process occurs in DMF as solvent at $-1.46 \mathrm{~V}$ vs. $\mathrm{Ag} / \mathrm{AgCl}$.

\section{${ }_{10}$ Introduction}

The most challenging electron transfer reductions, such as Birch reductions, ${ }^{1}$ acyloin couplings ${ }^{2,3}$ and reduction of dinitrogen in nitrogenase enzymes, ${ }^{4}$ are achieved by reactive metals and their 15 complexes. ${ }^{5}$ Recently, a number of organic electron donors have been synthesized that are very strong reducing agents (1-8). All of these compounds critically contain nitrogen atoms that are capable of stabilizing both positive charge and radical character, as the donors undergo oxidation. The aromaticity of their

20 oxidation products (radical cations and dications) following loss of one and two electrons respectively, also plays an important role in determining the strength of these electron donors. Table 1 compares the oxidation potentials of these compounds with the widely used sulfur-containing electron donor, tetrathiafulvalene 25 (TTF). ${ }^{6}$

Among the nitrogen-containing electron-donors, TDAE (1) is the parent compound in the series and the standard by which the others can be judged. ${ }^{7}$ Neither $\mathbf{1}$ nor its oxidized products is aromatic. Compound $\mathbf{2}$ could be considered anti-aromatic ${ }^{8}$ if 30 planar and so its oxidation through loss of two electrons might expect to be strongly driven; however it is quite deformed from planarity and it contains two aromatic pyrrole rings - as a result it is not a strong reducing agent. Compound $\mathbf{3}^{9}$ is already aromatic and hence its oxidation does not benefit from aromatization as a 35 driving force, and so it also is not a strong donor of electrons. In contrast, donors 4-8 are all converted into aromatic products upon oxidation ${ }^{10-19}$ and this adds to their strength as reducing agents. To illustrate the aromaticity that arises, the oxidation products of compound $\mathbf{8}$ are also shown in Figure 1. Loss of one 40 electron leads to radical cation $\mathbf{1 3}$ featuring one pyridinium ring, while loss of a second electron affords the aromatic disalt $\mathbf{1 4}$. In terms of the applications of these stronger electron donors, benzimidazole-derived $\mathbf{6}$ converts iodoarenes into aryl radicals, ${ }^{15}$ while the stronger donors $\mathbf{7}$ and $\mathbf{8}$ reduce the same substrates to 45 aryl anions. ${ }^{12,14}$ Donors 7 and $\mathbf{8}$ are also able to reduce arenesulfonamides, ${ }^{16}$ Weinreb amides ${ }^{17}$ and acyloin derivatives. ${ }^{18}$

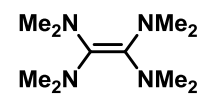

1

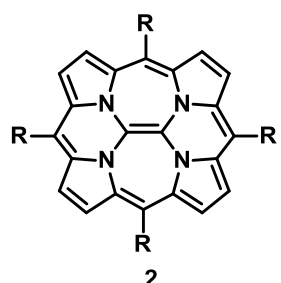

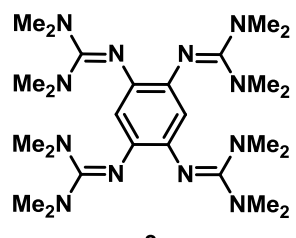

3

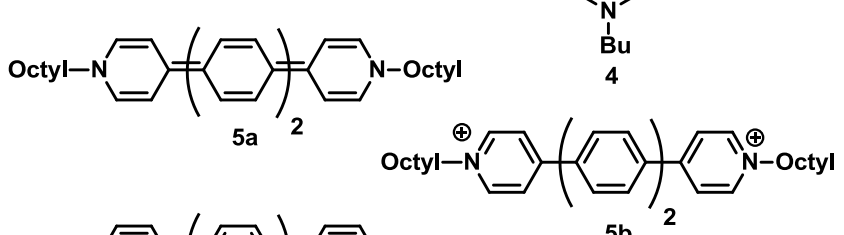

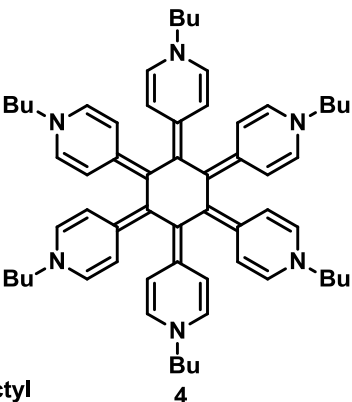

$5 b$<smiles></smiles>

8, $\mathrm{R}, \mathrm{R}=\left(\mathrm{CH}_{2}\right)_{3}$ $15, R=M e$

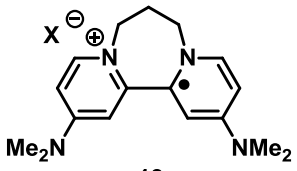

13

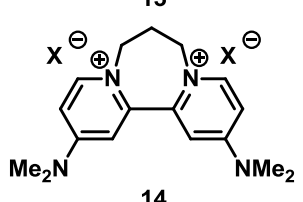

14

Figure 1 Known neutral organic electron donors 1-8 and related compounds. 
Table 1 Oxidation potentials of neutral organic electron donors.

\begin{tabular}{|l|l|l|l|l|l|}
\hline Compound & $E_{1 / 2}^{1}$ & $E_{1 / 2}^{2}$ & solvent & $E_{1 / 2}^{1}$ vs SCE (converted) & $E_{1 / 2 \text { vs SCE (converted) }}^{2}$ \\
\hline TTF $^{6}$ & $+0.37 \mathrm{~V}(\mathrm{SCE})$ & $+0.67 \mathrm{~V}(\mathrm{SCE})$ & $\mathrm{DCM}$ & $+0.37 \mathrm{~V}$ & $+0.67 \mathrm{~V}$ \\
\hline $\mathbf{1}^{7}$ & $-0.78 \mathrm{~V}(\mathrm{SCE})$ & $-0.61 \mathrm{~V}(\mathrm{SCE})$ & $\mathrm{MeCN}$ & $-0.78 \mathrm{~V}$ & $-0.61 \mathrm{~V}$ \\
\hline $\mathbf{2}^{8}$ & $-0.59 \mathrm{~V}\left(\mathrm{Fc} / \mathrm{Fc}^{+}\right)$ & $-0.26 \mathrm{~V}\left(\mathrm{Fc} / \mathrm{Fc}^{+}\right)$ & THF & $-0.14 \mathrm{~V}$ & $+0.19 \mathrm{~V}$ \\
\hline $3^{9}$ & $-0.32 \mathrm{~V}(\mathrm{SCE})$ & - & $\mathrm{MeCN}$ & $-0.32 \mathrm{~V}$ & - \\
\hline $\mathbf{4}^{13}$ & $-1.33 \mathrm{~V}\left(\mathrm{Fc} / \mathrm{Fc}^{+}\right)$ & $-1.14 \mathrm{~V}\left(\mathrm{Fc}_{\mathrm{fc}} / \mathrm{Fc}^{+}\right)$ & $\mathrm{DMF}$ & $-0.88 \mathrm{~V}$ & $-0.69 \mathrm{~V}$ \\
\hline $\mathbf{5}^{11}$ & $-1.48 \mathrm{~V}\left(\mathrm{Fc} / \mathrm{Fc}^{+}\right)$ & $-1.48 \mathrm{~V}\left(\mathrm{Fc} / \mathrm{Fc}^{+}\right)$ & THF & $-1.03 \mathrm{~V}$ & $-1.03 \mathrm{~V}$ \\
\hline $\mathbf{6}^{10}$ & $-0.82 \mathrm{~V}(\mathrm{SCE})$ & $-0.76 \mathrm{~V}(\mathrm{SCE})$ & $\mathrm{DMF}$ & $-0.82 \mathrm{~V}$ & $-0.76 \mathrm{~V}$ \\
\hline $7^{10}$ & $-1.20 \mathrm{~V}(\mathrm{SCE})$ & $-1.20 \mathrm{~V}(\mathrm{SCE})$ & $\mathrm{DMF}$ & $-1.20 \mathrm{~V}$ & $-1.20 \mathrm{~V}$ \\
\hline $\mathbf{8}^{14,19}$ & $-1.69 \mathrm{~V}\left(\mathrm{Fc} / \mathrm{Fc}{ }^{+}\right)$ & $-1.69 \mathrm{~V}\left(\mathrm{Fc} / \mathrm{Fc}^{+}\right)$ & $\mathrm{DMF}$ & $-1.24 \mathrm{~V}$ & $-1.24 \mathrm{~V}$ \\
\hline
\end{tabular}

5 Although these are highly reactive organic compounds, their reducing power is significantly less than that of the strongest metals (e.g. the oxidation potential of $\left.\mathrm{Li}, E^{0}=-3.02 \mathrm{~V}\right)^{20}$ and questions arise about whether a limit is being approached in the design of organic neutral donors.

10 Molecule 5a features a number of rings, all of which could become aromatic (5b) on loss of two electrons. ${ }^{11}$ However, if such a donor has a sufficient number of linked rings, the aromatic stabilization energy might ensure that the ground-state of $\mathbf{5 a}$ will instead be diradical $\mathbf{5 c}$ and then the oxidation to $\mathbf{5 b}$ 15 by loss of two electrons would only convert the two terminal rings to aromatic rings. Whether $\mathbf{5}$ exists as $\mathbf{5 a}$ or $\mathbf{5 c}$ is not entirely settled. The compound did not afford a well-defined NMR spectrum that would characterize a closed-shell structure, ${ }^{11}$ indicating that it might be a diradical, although no ${ }_{20}$ EPR evidence for radical character was seen. The second indication of a reactivity limit related to the imidazole-derived compounds 7, 9-12. Although the doubly trimethylene-tethered compound 7 has been fully characterized, efforts to make simpler analogues of this compound, for example 9-11, had 25 proved impossible. ${ }^{21,22}$ Attempted preparations of compound 11 had instead led to dicarbene 12, possibly through spontaneous rupture of the central alkene to the dicarbene, but more likely through activation by a proton source or by a metal cation ${ }^{23}$ the dicarbene $\mathbf{1 2}$ is not an electron donor. The instability of the 30 tetraazafulvalene central double-bond was evident also from calculations that showed bond strength for molecule $\mathbf{1 0}$ of only $4 \mathrm{~kJ}$ mole ${ }^{-1} .^{21}$ In fact, compound $\mathbf{9}$ and $\mathbf{1 0}$ have recently been prepared in our laboratories, ${ }^{24}$ but have been shown to be very short-lived.

\section{${ }_{35}$ Results and Discussion}

To probe whether more powerful donors could be prepared, it was therefore important to avoid compounds like 7 and 9-12. Compound $\mathbf{8}$ offered the best design lead. This compound was a purple solid and was stable in the absence of air and moisture.
${ }_{40}$ Unlike imidazole-derived 7, which required both trimethylene bridges, it had been possible to synthesise some analogues of the pyridine-derived $\mathbf{8}$, including the compound $\mathbf{1 5}$ that features no trimethylene bridges. These compounds were, together with 7 , the strongest neutral organic ground-state donors known. To 45 enhance the donor strength, two possibilities were considered: (i) introduction of appropriately placed electron-releasing substituents on the pyridine-derived rings or (ii) extension of the polycyclic system by inclusion of more rings. We recently reported that our initial efforts to prepare analogues derived from ${ }_{50}$ 2-(dialkylamino)pyridines had led in an unexpected direction ${ }^{25,26}$ but we now address both points in extending the polycyclic system.

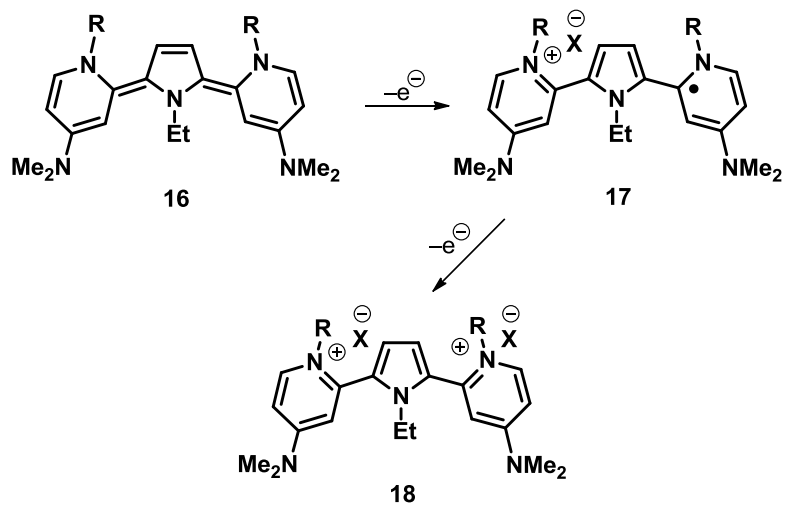

Scheme 1 Proposed new electron donors 16.

The strategy for development of extended donors and more powerful donors involved using pyrrole-derived units. Interpolation of a pyrroldiylidene between the two pyridinederived rings of donor 15 would result in $16 .{ }^{27-30}$ Here, five 60 nitrogen atoms would stabilize the transition states and products of oxidation, and three rings would develop aromaticity in the 
two-electron conversion to pyrrole-dipyridinium salt $\mathbf{1 8}$ (Scheme 1).

The synthesis of $\mathbf{1 6}$ was achieved as shown in scheme $2 .{ }^{31}$ Initially, the synthesis of diketone $\mathbf{2 2}$ directly from Weinreb 5 amide 19 and 4-DMAP 20 was attempted using Fort's direct deprotonation protocol, ${ }^{32}$ however this was unsuccessful. $\operatorname{Kessar}^{33}$ used $N$-trifluoroboration of pyridine to acidify the 2position of the ring, and the resulting pyridinium ylid was used for $\mathrm{C}-\mathrm{C}$ bond-formation. The same $\mathrm{BF}_{3}$ adduct has also been 10 utilized by Sammakia ${ }^{34}$ and Vedejs. ${ }^{35}$ The trifluoroborate salt was easily prepared (76\% yield) from reaction of $\mathbf{2 0}$ with $\mathrm{BF}_{3} \cdot \mathrm{Et}_{2} \mathrm{O}$ followed by filtration of the hygroscopic white solid. Formation of diketone $\mathbf{2 2}$ from lithiation of the $\mathrm{BF}_{3}$ adduct was unsuccessful using LDA, $n$-BuLi or $t$-BuLi and so a lithium-

15 halogen exchange using 2-bromo-4-DMAP 21 followed by addition of Weinreb amide 19 was attempted. The synthesis of 21 was successful and optimized by forming the trifluoroborate adduct in situ and using tetrabromomethane as the halogenation source, as opposed to bromine. A minor side-product $\mathbf{2 3}$ arose 20 from nucleophilic attack by $t$-BuLi. From 22, formation of the central pyrrole ring to give compound $\mathbf{2 4}$ was efficient, as was the methylation of the pyridine rings to give dication 25 (79\% and $96 \%$ yields respectively, scheme 2 ).

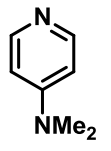

20

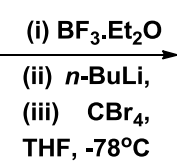

(i) $t$-BuLi, THF, $-78^{\circ} \mathrm{C}$<smiles>CON(C)C(=O)CCC(=O)N(C)C</smiles>

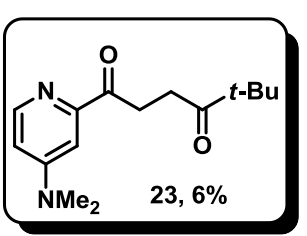<smiles>CN(C)c1ccnc(C(=O)CCC(=O)c2cc(N(C)C)ccn2)c1</smiles>

$\mathrm{EtNH}_{2}$ (dist.) EtOH
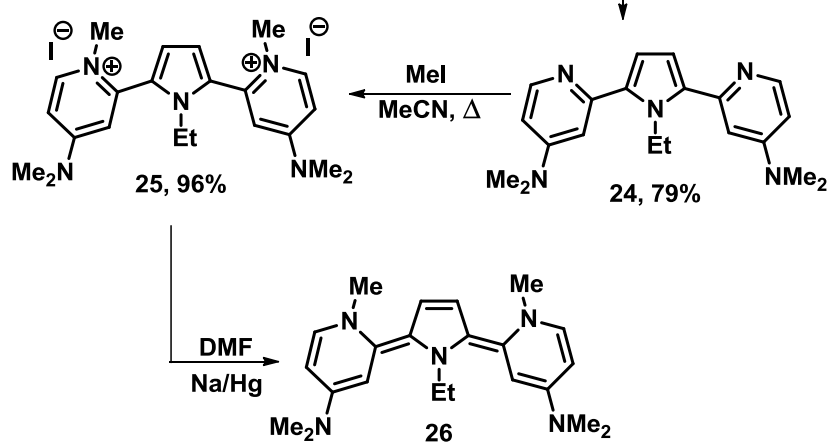

25 Cyclic voltammetry of compound 25 (figure 2 shows the voltammogram together with that of 14) revealed a reversible two-electron wave at $E_{1 / 2}=-1.46 \mathrm{~V}$ vs. $\mathrm{Ag} / \mathrm{AgCl}$ in $\mathrm{DMF}$ (equating to $-1.50 \mathrm{~V} v s$. SCE). This is $260 \mathrm{mV}$ more negative 30 than the half-wave potential for $\mathbf{8}$, and so compound $\mathbf{2 6}$ is now by far the most powerful neutral ground-state organic electron donor yet synthesized. Donor $\mathbf{2 6}$ was prepared by reduction of disalt 25 with sodium amalgam in DMF. The compound was then removed from the amalgam for analysis and to explore its 35 reactivity.
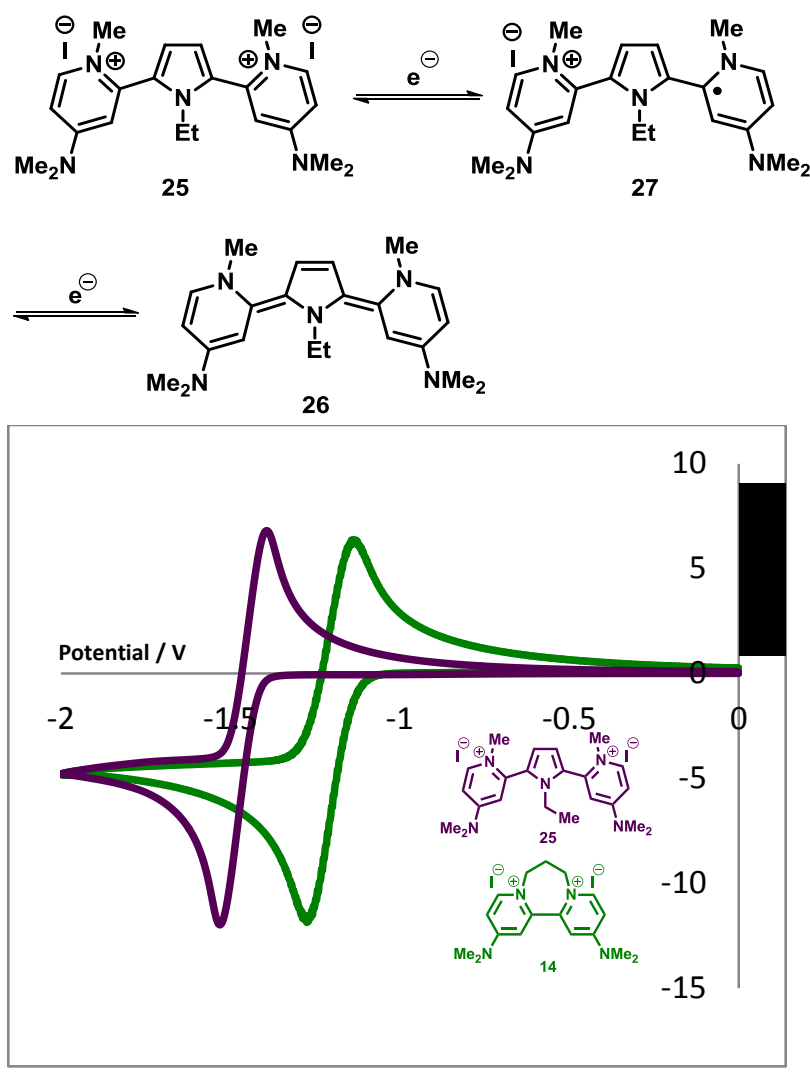

Figure 2 Comparison of cyclic voltammograms of 25 (purple) and 14 40 (green) $v s . \mathrm{Ag} / \mathrm{AgCl}$ in $\mathrm{DMF}$ at $50 \mathrm{mV} \mathrm{s}^{-1}$ scan rate.

Characterisation of $\mathbf{2 6}$ proved interesting. As previously seen for compound $\mathbf{5}$, this compound did not give a well resolved ${ }^{1} \mathrm{H}$ NMR spectrum in DMF-d $\mathrm{d}_{7}$. Attempts to achieve a sharper spectrum by cooling, or by heating to $90{ }^{\circ} \mathrm{C}$, were not 45 successful, and so we sought further information at room temperature. To do this, ESR spectra were recorded and a weak signal detected that was consistent with an organic radical, but not with a triplet diradical. This species may be the radical cation $\mathbf{2 7}$ or may be another radical derived from $\mathbf{2 6}$. ${ }_{50}$ Quantitative ESR measurements undertaken using diphenylpicrylhydrazyl (DPPH) as a calibrant indicated that the radical concentration accounted for only $0.012 \%$ of the concentration of $\mathbf{2 6}$, and so this cannot be the cause of the broadness in the NMR spectrum. The alternative possibility of 55 rotation about the inter-ring $\mathrm{C}=\mathrm{C}$ bonds through a suitable lowenergy triplet was also explored. A low energy triplet (M052X/cc-pVTZ: $\Delta U_{\mathrm{T}, \text { calc }}=11.0(12.9) \mathrm{kcal} \mathrm{mol}^{-1}$, gas phase (DMF)) exists (see SI file); however since this is not observed in ESR, it could only be a conduit between configurational 60 isomers about the inter-ring $\mathrm{C}=\mathrm{C}$ bonds. However, the energies 
of the configurational isomers are very high relative to $\mathbf{2 6}$, (density functional calculations using the B3LYP 6-31G* functional in a DMF continuum show that changing one of the inter-ring alkenes from $E$ to $Z$ affords the next most favourable 5 isomer, but that is $23 \mathrm{kcal} /$ mole higher in energy than 26) and accordingly, populations of minor isomers arising in this way are unlikely as the cause of the broad signals in the NMR spectrum.

The product of the oxidation of $\mathbf{2 6}$ by molecular iodine was 10 characterized as the diiodide salt $\mathbf{2 5}$. Further characterization of donor 26 was achieved through performing the experiment quantitatively by using titration. The compound $\mathbf{2 6}$ was treated with excess iodine to afford 25; following this reaction, the unreacted residual iodine was then back-titrated with sodium 15 thiosulfate. This titration showed that the donor had reacted with exactly one equivalent of iodine, in line with expectation for two-electron donor $\mathbf{2 6}$.
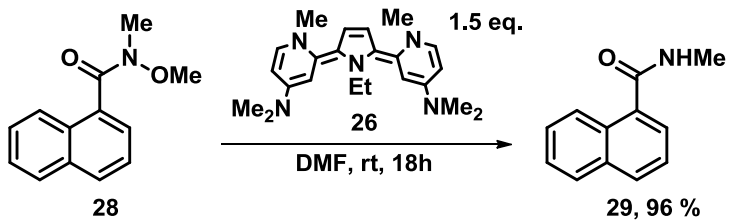

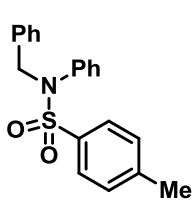

30

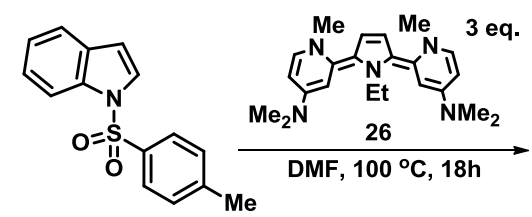

32

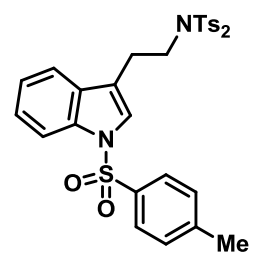

34
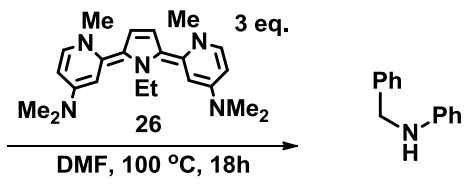

$31,68 \%$

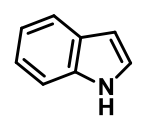

$33,87 \%$

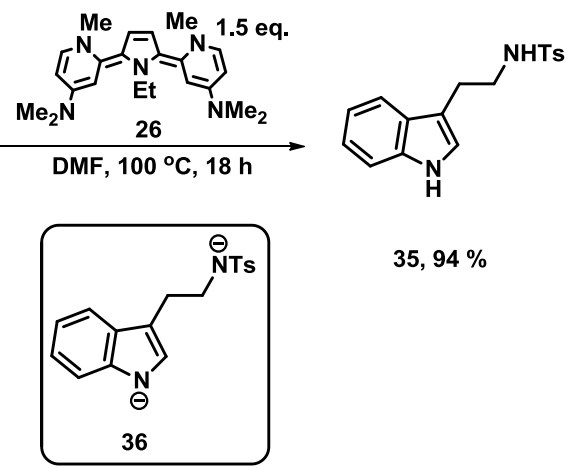

${ }_{20}$ Scheme 3 Reduction of organic substrates using donor 26.

The reactivity of $\mathbf{2 6}$ towards organic substrates was now tested. Donor 26 reduced Weinreb amide 28 (96\% yield) using just 1.5 eq. of donor at room temperature (Scheme 3). Reduction of tosylamides 30, 32 and $\mathbf{3 4}$ was then carried out. Substrate $\mathbf{3 0}$

25 was of interest as 4-DMAP-based donor $\mathbf{8}$ had reduced substrate 30 with difficulty in $22 \%$ yield at $100{ }^{\circ} \mathrm{C}$, and six equivalents of imidazole-based donor 7 had been required to reduce 32 in $96 \%$ yield at $110{ }^{\circ} \mathrm{C}$. However, donor 26 now reduced 30 and 32 in $68 \%$ and $87 \%$ yield respectively, both

30 times requiring only 3 equivalents of donor at $100{ }^{\circ} \mathrm{C}$ indicating that it is more efficient at performing difficult reductions. It has been previously established that the deprotection of these sulfonamides affords nitrogen anions and sulfinate anions. In this way, reaction of substrate $\mathbf{3 4}$ affords dianion 36, leading to 35 isolated sulfonamide $\mathbf{3 5}$, on workup. Overall, pyrroldiylidene donor 26 represents a new generation of highly electron-rich and purely organic reducing agents with a half-wave potential of $-1.5 \mathrm{~V} v s$. SCE and the ability to carry out ever more challenging reductions.

\section{${ }_{40}$ Conclusions}

A new powerful neutral organic electron donor $\mathbf{2 6}$ has been synthesized and is able to reduce appropriate tosylamides with greater efficiency than any previously synthesized neutral organic donor. With a half-wave potential of $-1.46 \mathrm{~V} v s$. ${ }_{45} \mathrm{Ag} / \mathrm{AgCl}$ in DMF (equating to of $-1.5 \mathrm{~V} v s$. SCE), it is the most reducing neutral organic species known.

\section{Experimental Section}

${ }_{50}$ General: Proton NMR $\left({ }^{1} \mathrm{H}\right)$ spectra were recorded at $500 \mathrm{MHz}$ (on a Bruker ${ }^{\circledR} \mathrm{AV} 500^{\mathrm{TM}}$ spectromer) or at $400.13 \mathrm{MHz}$ (on a Bruker $^{\circledR}$ DPX $400^{\mathrm{TM}}$ or Bruker ${ }^{\circledR}$ AV400 ${ }^{\mathrm{TM}}$ spectrometer). Carbon NMR $\left({ }^{13} \mathrm{C}\right)$ spectra were recorded at $125 \mathrm{MHz}$ or 100 $\mathrm{MHz}$ using a J-mod pulse program to determine carbon 55 assignments. Experiments were carried out using deuterated chloroform $\left(\mathrm{CDCl}_{3}\right)$ unless otherwise stated and chemical shifts are reported in parts per million (ppm), calibrated on the solvent residual peak and referenced to tetramethylsilane. Coupling constants $J$ are reported in Hertz $(\mathrm{Hz})$. The following 60 abbreviations are used for the multiplicities: s, singlet; $d$, doublet; t, triplet; q, quartet; m, multiplet; bs, broad singlet.

High resolution mass spectra were recorded at the EPSRC National Mass Spectrometry Service Centre, Swansea on a JLZX $102^{\mathrm{TM}}$, VGZAB-ETM or a VG $\mathrm{VG}^{\mathrm{TM}}$ micromass instrument.

${ }_{65}$ Low resolution mass spectra were recorded at the University of Strathclyde Mass Spectrometry Service on a ThermoFinnigan ${ }^{\mathrm{TM}}$ PolarisQ Ion Trap Spectrometer and trace GC instrument using a ZB-5 column (30 metres).

Infrared spectra were recorded on a Perkin Elmer Spectrum One ${ }_{70} \mathrm{FT} \mathrm{IR}^{\mathrm{TM}}$ spectrometer as films applied on sodium chloride plates or mixed and pressed into potassium bromide disks. Melting points were recorded using either a Griffin or a Gallenkamp melting point apparatus.

Column chromatographies on silica gel were performed using 75 Prolabo 35-75 $\mu \mathrm{m}$ particle sized silica gel 60 (200-400 mesh). Crude mixtures were studied using thin layer chromatography (TLC) carried out on Merck silica gel $60 \mathrm{~F}_{254}$ precoated aluminium plates. Visualization was achieved under UVP mineralight UVG-11 lamp or by developing plates with 80 methanolic vanillin or potassium permanganate.

Concentration of solutions under reduced pressure (1-10 mbar) was achieved using a diaphragm pump vacuum. Drying of solids under reduced pressure was performed at room 
temperature firstly under 1-10 mbar using a diaphragm pump vacuum then under 0.001-0.01 mbar using a rotary oil pump.

All reagents were obtained from commercial suppliers and used without further purification unless stated otherwise.

5 Tetrahydrofuran, dichloromethane, hexane, diethyl ether and toluene were dried and deoxygenated with a Pure-Solv 400 solvent purification system (by Innovative Technology Inc., USA). $n$-BuLi was obtained as a $2.5 \mathrm{M}$ solution in hexane and $t$-BuLi as a 1.7 solution in hexane. Titration of both reagents, 10 prior to use, was achieved by dropwise addition of either reagent solution via syringe to a solution of diphenylacetic acid (1 mmol) in THF $(10 \mathrm{~mL})$ under argon. Addition was stopped with the first appearance of a yellow colour (diphenylacetate dianion) and the volume of lithiating reagent was measured.

15 The procedure was carried out in triplicate so that an average concentration could be calculated for each reagent. $\mathrm{N}, \mathrm{N}$ Dimethylformamide was obtained from commercial suppliers as anhydrous (99.98\%) and used directly. Sodium hydride was supplied as a $60 \%$ suspension in mineral oil and was washed 20 with hexane to remove oil prior to use. Dry acetonitrile was dried by distillation over phosphorus pentoxide. All reactions were carried out under argon unless otherwise stated.

\section{Calculations}

25 All calculations were performed using the Gaussian09 suite of programs. ${ }^{36}$ The M05-2X hybrid functional ${ }^{37}$ was employed in combination with a cc-pVTZ basis set. ${ }^{38}$ All stationary points were fully optimised and characterised via a vibrational analysis. The influence of solvation was taken into account via 30 a polarisable continuum model $(\mathrm{scrf}=\mathrm{pcm}) .{ }^{39}$

\section{Cyclic Voltammetry conditions}

Cyclic voltamograms were carried out using a glassy carbon working electrode, $\mathrm{Ag} / \mathrm{AgCl}$ reference electrode and platinum 35 counter electrode. The electrolyte solution used was $0.1 \mathrm{M}$ tetrabutylammonium hexafluorophosphate in degassed anhydrous DMF and the concentrations of the ferrocene external standard and analyte were also $0.1 \mathrm{M}$. All solutions were prepared in the glovebox under an inert atmosphere. A 40 three-electrode set up was used to obtain the cyclic voltammograms. Electrochemical measurements were carried out using the Autolab $\AA /$ PGSTAT302N potentiostat.

\section{General procedure for Reductions using Pyrrole-based 45 Tricyclic Electron Donor}

Sodium amalgam was prepared by addition of freshly cut sodium $(50 \mathrm{mg})$ to a flame-dried $25 \mathrm{~mL}$ round bottom flask containing mercury $(5 \mathrm{~g})$ under a strong flow of argon. To this was added anhydrous DMF (15 mL) followed by pyrrole-based diiodide salt ${ }_{50}$ 25. The formation of a deep purple colour indicated donor formation and at this stage the reaction was left stirring for $3 \mathrm{~h}$ to ensure reaction had gone to completion. The purple solution was transferred by cannula to a flask containing the desired substrate and left to stir overnight at the stated temperature. There was no 55 transfer of sodium amalgam to the flask containing the substrate. This was further verified by inspecting the flask for traces of mercury at the work-up stage. The reaction solution was partitioned between EtOAc $(100 \mathrm{~mL})$ and water $(50 \mathrm{~mL})$. The organic phase was washed with water $(2 \times 50 \mathrm{~mL})$ to remove 60 traces of DMF and brine $(50 \mathrm{~mL})$. After drying over $\mathrm{Na}_{2} \mathrm{SO}_{4}$ and concentrating under reduced pressure, the residue was purified using column chromatography with the stated eluent mixture.

\section{Preparation of $N, N^{\prime}$-dimethoxy- $N, N^{\prime}$-dimethylsuccinamide} 65 19:

Potassium hydroxide (50.95 g, 908 mmol, 6 eq.) was added to a solution of $\mathrm{N}, \mathrm{O}$-dimethylhydroxylamine hydrochloride $(59.05 \mathrm{~g}$, $605 \mathrm{mmol}, 4$ eq. $)$ in water $(150 \mathrm{~mL})$ slowly at $0{ }^{\circ} \mathrm{C}$ with vigorous stirring. The free amine was distilled from the solution at $42{ }^{\circ} \mathrm{C}$ 70 and added via dropping funnel to a solution of succinyl chloride (16.6 mL, $151 \mathrm{mmol}, 1$ eq.) in dry DCM $(300 \mathrm{~mL})$ under argon at $-10{ }^{\circ} \mathrm{C}$ with vigorous stirring. The reaction mixture was brought to room temperature and left stirring under argon atmosphere for $16 \mathrm{~h}$. The reaction mixture was concentrated under reduced 75 pressure to $100 \mathrm{~mL}$, washed with $0.5 \mathrm{M}$ hydrochloric acid $(5 \times 50$ $\mathrm{mL}), \mathrm{NaHCO}_{3(\mathrm{aq})}(3 \times 50 \mathrm{~mL})$, brine $(50 \mathrm{~mL})$ and dried over $\mathrm{Na}_{2} \mathrm{SO}_{4}$. The crude solution was concentrated under reduced pressure and purified by column chromatography (firstly with neat EtOAc to remove less polar impurities then $20 \%$ $80 \mathrm{MeOH} / \mathrm{EtOAc}$ ) to afford $N, N^{\prime}$-dimethoxy- $N, N^{\prime}$-dimethylsuccinamide 19 (20.1 g, 65\%) as a clear oil, which crystallised on standing to give white crystals; m.p. $73-75{ }^{\circ} \mathrm{C}$ (lit. ${ }^{40}: 73-75{ }^{\circ} \mathrm{C}$ ); [Found: $\left(\mathrm{ESI}^{+}\right)(\mathrm{M}+\mathrm{H})^{+}$205.1185, $\mathrm{C}_{8} \mathrm{H}_{17} \mathrm{~N}_{2} \mathrm{O}_{4}(\mathrm{MH})$ requires 205.1183]; $v_{\max }($ film $) / \mathrm{cm}^{-1}$ 3493, 2963, 2942, 2830, 1731, 1660, 85 1460, 1422, 1390, 1194, 1097, 994, 934, 795, 745; ${ }^{1} \mathrm{H}-\mathrm{NMR}(500$ $\left.\mathrm{MHz}, \mathrm{CDCl}_{3}\right) \delta 2.78\left(4 \mathrm{H}, \mathrm{s}, \mathrm{CH}_{2}\right), 3.12\left(6 \mathrm{H}, \mathrm{s}, \mathrm{NCH}_{3}\right), 3.74(6 \mathrm{H}$, $\left.\mathrm{s}, \mathrm{OCH}_{3}\right) ;{ }^{13} \mathrm{C}-\mathrm{NMR}\left(125 \mathrm{MHz}, \mathrm{CDCl}_{3}\right) \delta 25.9\left(\mathrm{CH}_{2}\right), 31.1$ $\left(\mathrm{NCH}_{3}\right), 60.7\left(\mathrm{OCH}_{3}\right), 172.9(\mathrm{C}) ; \mathrm{m} / \mathrm{z}\left(\mathrm{ESI}^{+}\right) 205\left([\mathrm{M}+\mathrm{H}]^{+}\right.$, $100 \%), 239$ (21), 351 (7), 515 (2).

90

Preparation of 2-bromo-4-dimethylaminopyridine 21

(a) preparation of 4-dimethylaminopyridinium trifluoroborate:

To a solution of 4-dimethylaminopyridine $(4.89 \mathrm{~g}, 40 \mathrm{mmol}, 1$ eq.) in a 1:1 mixture of dry THF $(50 \mathrm{~mL})$ and $\mathrm{Et}_{2} \mathrm{O}(50 \mathrm{~mL})$ was 95 added boron trifluoride diethyl etherate $(6.01 \mathrm{~mL}, 48.9 \mathrm{mmol}$, 1.22 eq.) dropwise. The white suspension was stirred at room temperature for $3 \mathrm{~h}$ and the precipitate was filtered via argon pressure onto a sinter funnel. The white solid was dissolved in DCM $(100 \mathrm{~mL})$, washed with water $(2 \times 50 \mathrm{~mL})$, brine $(50 \mathrm{~mL})$, 100 dried over $\mathrm{Na}_{2} \mathrm{SO}_{4}$ and concentrated under reduced pressure to afford 4-dimethylaminopyridinium trifluoroborate (5.80 g, 76\%) as a white solid; mp: $128-130{ }^{\circ} \mathrm{C}$ (lit.: $\left.{ }^{41} 129.8-130.9{ }^{\circ} \mathrm{C}\right)$; [Found: $\left(\mathrm{ESI}^{+}\right)\left(\mathrm{M}+\mathrm{NH}_{4}\right)^{+}$208.1226; $\mathrm{C}_{7} \mathrm{H}_{14}\left({ }^{11} \mathrm{~B}\right) \mathrm{F}_{3} \mathrm{~N}_{3},\left(\mathrm{M}+\mathrm{NH}_{4}\right)$ requires 208.1227]; $v_{\max }(\mathrm{KBr}) / \mathrm{cm}^{-1} 2939,1646,1568,1404,1113,914$; $105{ }^{1} \mathrm{H}-\mathrm{NMR}\left(400 \mathrm{MHz}, \mathrm{CDCl}_{3}\right) \delta 3.18\left(6 \mathrm{H}, \mathrm{s}, \mathrm{NCH}_{3}\right), 6.64(2 \mathrm{H}, \mathrm{s}, J$ $=7.3 \mathrm{~Hz}, \mathrm{ArH}), 8.12(2 \mathrm{H}, \mathrm{d}, J=7.3 \mathrm{~Hz}, \mathrm{ArH}) ;{ }^{13} \mathrm{C}-\mathrm{NMR}(125$ $\left.\mathrm{MHz}, \mathrm{CDCl}_{3}\right) \delta 40.0\left(\mathrm{CH}_{3}\right), 106.3(\mathrm{CH}), 142.2(\mathrm{CH}), 156.9(\mathrm{C})$; ${ }^{19} \mathrm{~F}-\mathrm{NMR}\left(125 \mathrm{MHz}, \mathrm{CDCl}_{3}\right) \delta$ 152.07-152.18 $\left(\mathrm{BF}_{3}\right) ; \mathrm{m} / z\left(\mathrm{ESI}^{+}\right)$ $207\left(\left[\mathrm{M}+\mathrm{NH}_{4}\right]^{+},{ }^{10} \mathrm{~B}, 22 \%\right), 208\left(\left[\mathrm{M}+\mathrm{NH}_{4}\right]^{+11} \mathrm{~B}, 100 \%\right), 213$ $110\left[(\mathrm{M}+\mathrm{Na})^{+}, 68\right], 231(13)$.

(b) preparation of 2-bromo-4-dimethylaminopyridine $\mathbf{2 1}$ :

To a solution of 4-dimethylaminopyridine $(25.45 \mathrm{~g}, 208 \mathrm{mmol}, 1$ eq.) in dry THF $(300 \mathrm{~mL})$ at room temperature was added freshly 115 purchased boron trifluoride diethyl etherate $(30.9 \mathrm{~mL}, 250 \mathrm{mmol}$, 1.2 eq.) and solution was stirred for $30 \mathrm{~min}$ before cooling to -78 ${ }^{\circ} \mathrm{C}$ under vigorous flow of argon. $n$-BuLi in hexane $(100 \mathrm{~mL}, 250$ mmol, 1.2 eq.) was added dropwise under argon to the cream coloured suspension, keeping the temperature below $-70{ }^{\circ} \mathrm{C}$. After $12030 \mathrm{~min}$, a solution of carbon tetrabromide $(82.91 \mathrm{~g}, 250 \mathrm{mmol}$, 1.2 eq.) in dry THF (100 mL) was added dropwise via cannula 
under argon (again keeping temperature below $-70{ }^{\circ} \mathrm{C}$ ) and the dark brown reaction mixture was left to warm to room temperature overnight. THF was removed under reduced pressure and the residue was partitioned between DCM $(250 \mathrm{~mL})$ and sat. $5 \mathrm{NaHCO}_{3 \text { (aq) }}(100 \mathrm{~mL})$. The organic layer was washed with sat. $\mathrm{NaHCO}_{3(\mathrm{aq})}(2 \times 100 \mathrm{~mL})$, brine $(100 \mathrm{~mL})$ and dried over $\mathrm{Na}_{2} \mathrm{SO}_{4}$. The crude solution was concentrated under reduced pressure and purified by column chromatography (10-30\% EtOAc/Hexane) to afford 2-bromo-4-dimethylaminopyridine 21 (30.59 g, 75\%) as 10 an orange semi-solid; [Found: $\left(\mathrm{ESI}^{+}\right) \quad(\mathrm{M}+\mathrm{H})^{+}$202.0022; $\mathrm{C}_{7} \mathrm{H}_{9}\left({ }^{79} \mathrm{Br}\right) \mathrm{N}_{2}$ requires $\left.\mathrm{MH}, 202.0022\right] ; v_{\max }($ film $) / \mathrm{cm}^{-1} 2932$, 2820, 1594, 1520, 1441, 1222, 1131, 1073, 978; ${ }^{1} \mathrm{H}-\mathrm{NMR}(500$ $\left.\mathrm{MHz}, \mathrm{CDCl}_{3}\right) \delta 2.99\left(6 \mathrm{H}, \mathrm{s}, \mathrm{NCH}_{3}\right) ; 6.43(1 \mathrm{H}, \mathrm{dd}, J=2.5 \mathrm{~Hz}, 6$ $\mathrm{Hz}, \operatorname{ArH}) ; 6.63(1 \mathrm{H}, \mathrm{d}, J=2.5 \mathrm{~Hz}, \operatorname{ArH}) ; 7.93(1 \mathrm{H}, \mathrm{d}, J=6 \mathrm{~Hz}$, $15 \mathrm{ArH}) ;{ }^{13} \mathrm{C}-\mathrm{NMR}\left(125 \mathrm{MHz}, \mathrm{CDCl}_{3}\right) \delta 39.5\left(\mathrm{NCH}_{3}\right), 106.4(\mathrm{CH})$, $109.4(\mathrm{CH}), 143.2(\mathrm{C}), 149.5(\mathrm{CH}), 156.0(\mathrm{C}) ; \mathrm{m} / \mathrm{z}\left(\mathrm{CI}^{+}\right) 202$ $\left.([\mathrm{M}+\mathrm{H}]]^{+},{ }^{79} \mathrm{Br}, 63 \%\right), 204\left([\mathrm{M}+\mathrm{H}]+{ }^{+},{ }^{81} \mathrm{Br}, 4 \%\right), 123$ (100). Data were consistent with precedent. ${ }^{42}$

20 Preparation of 1,4-bis-(4-dimethylamino-2-pyridyl)butane1,4-dione 22, with 1-(4-dimethylamino-2-pyridyl)-5,5dimethylhexane-1,4-dione 23 as by-product.

To a solution of 2-bromo-4-dimethylaminopyridine 21 (300 mg, $1.49 \mathrm{mmol}, 2.05$ eq. $)$ in dry THF $(20 \mathrm{~mL})$ at $-78{ }^{\circ} \mathrm{C}$ under argon 25 was added $t$-BuLi (2.01 mL, $3.02 \mathrm{mmol}, 4.15$ eq.) dropwise using argon pressure. The reaction was stirred for $60 \mathrm{~min}$ and a solution of $N, N^{\prime}$-dimethoxy- $N, N^{\prime}$-dimethylsuccinamide (149 $\mathrm{mg}, 0.73$ mmol, 1 eq.) in THF (10 mL) was added dropwise using argon pressure. The reaction was then left to warm to room temperature 30 overnight. After quenching the reaction by dropwise addition of water $(5 \mathrm{~mL})$, THF was removed under reduced pressure. The red residue was dissolved in DCM $(40 \mathrm{~mL})$ and washed with water $(2$ x $20 \mathrm{~mL})$, sat. $\mathrm{NaHCO}_{3}$ (aq) $(1 \times 20 \mathrm{~mL})$, brine $(1 \times 20 \mathrm{~mL})$ and dried over $\mathrm{Na}_{2} \mathrm{SO}_{4}$. The crude solution was concentrated under 35 reduced pressure and purified by column chromatography $(1 \%$ $\mathrm{Et}_{3} \mathrm{~N} / \mathrm{EtOAc}$ ). Since the product is insoluble in EtOAc, the crude material was washed with EtOAc in a sinter funnel to remove unreacted 4-dimethylaminopyridine. The yellow solid was then dried under reduced pressure to afford 1,4-bis-(4-dimethylamino40 2-pyridyl)-butane-1,4-dione 22 (5.3 g, 49\%) as a yellow powder; m.p. $165-167{ }^{\circ} \mathrm{C}$; [Found: $\left(\mathrm{EI}^{+}\right)\left(\mathrm{M}^{+}\right) 326.2 ; \mathrm{C}_{18} \mathrm{H}_{22} \mathrm{~N}_{4} \mathrm{O}_{2}$ requires $\left.\mathrm{M}^{+}, 326.2\right]$; $v_{\max }$ (film) $/ \mathrm{cm}^{-1}$ 2924, 1692, 1600, 1509, 1432, 1377, 1226, 985, 810; ${ }^{1} \mathrm{H}-\mathrm{NMR}\left(400 \mathrm{MHz}, \mathrm{CDCl}_{3}\right) \delta 3.04(12 \mathrm{H}, \mathrm{s}$, $\left.\mathrm{NCH}_{3}\right), 3.64\left(4 \mathrm{H}, \mathrm{s}, \mathrm{CH}_{2}\right), 6.63(2 \mathrm{H}, \mathrm{dd}, J=2.5 \mathrm{~Hz}, 6 \mathrm{~Hz}, \mathrm{ArH})$, ${ }_{45} 7.31(2 \mathrm{H}, \mathrm{d}, J=2.5 \mathrm{~Hz}, \mathrm{ArH}), 8.31(2 \mathrm{H}, \mathrm{d}, J=6 \mathrm{~Hz}, \mathrm{ArH}) ;{ }^{13} \mathrm{C}-$ NMR (125 MHz, $\left.\mathrm{CDCl}_{3}\right) \delta 32.5\left(\mathrm{CH}_{2}\right), 39.2\left(\mathrm{NCH}_{3}\right), 104.9(\mathrm{CH})$, $109.2(\mathrm{CH}), 149.1(\mathrm{CH}), 153.7(\mathrm{C}), 155.1(\mathrm{C}), 201.6(\mathrm{C}) ; \mathrm{m} / \mathrm{z}$ $\left(\mathrm{EI}^{+}\right) 326\left(\left[\mathrm{M}^{+}\right], 100 \%\right), 327(21), 328(5)$.

1-(4-Dimethylamino-2-pyridyl)-5,5-dimethylhexane-1,4-dione 23 $50(623 \mathrm{mg}, 6.5 \%)$ was also separately isolated as a yellow oil [Found: $\left(\mathrm{ESI}^{+}\right)(\mathrm{M}+\mathrm{H})^{+}$263.1757; $\mathrm{C}_{15} \mathrm{H}_{22} \mathrm{~N}_{2} \mathrm{O}_{2}$ requires $\mathrm{MH}$, 263.1754]; $v_{\max }\left(\right.$ film) $/ \mathrm{cm}^{-1} 2966,1698,1601,1540,1509,1432$, 1376, 1224, 1054, 985, 947, 818, ${ }^{1} \mathrm{H}-\mathrm{NMR}\left(500 \mathrm{MHz}, \mathrm{CDCl}_{3}\right) \delta$ $1.14\left(9 \mathrm{H}, \mathrm{s}, \mathrm{CH}_{3}\right), 2.86\left(2 \mathrm{H}, \mathrm{t}, J=6 \mathrm{~Hz}, \mathrm{CH}_{2}\right), 2.95(6 \mathrm{H}, \mathrm{s}$, $\left.{ }_{55} \mathrm{NCH}_{3}\right), 3.39\left(2 \mathrm{H}, \mathrm{t}, J=6 \mathrm{~Hz}, \mathrm{CH}_{2}\right), 6.53(2 \mathrm{H}, \mathrm{dd}, J=2.5 \mathrm{~Hz}, 6$ $\mathrm{Hz}, \mathrm{ArH}), 7.17(2 \mathrm{H}, \mathrm{d}, J=2.5 \mathrm{~Hz}, \mathrm{ArH}), 8.20(2 \mathrm{H}, \mathrm{d}, J=6 \mathrm{~Hz}$, $\mathrm{ArH}) ;{ }^{13} \mathrm{C}-\mathrm{NMR}\left(125 \mathrm{MHz}, \mathrm{CDCl}_{3}\right) \delta 26.6\left(\mathrm{CH}_{3}\right), 30.8\left(\mathrm{CH}_{2}\right)$, $32.0\left(\mathrm{CH}_{2}\right), 39.1\left(\mathrm{NCH}_{3}\right), 43.9(\mathrm{C}), 104.6(\mathrm{CH}), 109.2(\mathrm{CH})$, $149.0(\mathrm{CH}), 153.5(\mathrm{C}), 154.8$ (C), $201.6(\mathrm{C}), 214.4$ (C); $\mathrm{m} / \mathrm{z}$ $60\left(\mathrm{ESI}^{+}\right) 263\left([\mathrm{M}+\mathrm{H}]^{+}, 100 \%\right), 264(16), 265(5)$.
Preparation of $\mathrm{N}$-ethyl-2,5-bis-(4-dimethylamino-2-pyridyl)pyrrole 24:

${ }_{65}$ To a solution of 1,4-bis-(4-dimethylamino-2-pyridyl)butane-1,4dione 22 (1.56 g, $4.79 \mathrm{mmol}, 1$ eq.) in methanol $(10 \mathrm{~mL})$ was added freshly distilled ethylamine ${ }_{(\mathrm{aq})}(20 \mathrm{~mL}$, excess $)$. The reaction was stirred at room temperature overnight and concentrated under reduced pressure. The residue was purified by 70 column chromatography (EtOAc to $2 \% \mathrm{Et}_{3} \mathrm{~N} / \mathrm{EtOAc}$ ) and washed in a sinter funnel with diethyl ether to remove further impurities to afford $\mathrm{N}$-ethyl-2,5-bis-(4-dimethylamino-2-pyridyl)pyrrole $\mathbf{2 4}$ $(1.26 \mathrm{~g}, 79 \%)$ as a light brown semi-solid; [Found: $\left(\mathrm{ESI}^{+}\right)$ $(\mathrm{M}+\mathrm{H})^{+} 336.2185, \mathrm{C}_{20} \mathrm{H}_{25} \mathrm{~N}_{5}$ requires $\left.\mathrm{MH}, 336.2183\right]$; $v_{\max }(\mathrm{KBr})$ $75 / \mathrm{cm}^{-1}$ 3091, 2978, 2927, 2814, 1593, 1542, 1501, 1443, 1370, 1325, 1278, 1224, 989, 804, 770; ${ }^{1} \mathrm{H}-\mathrm{NMR}\left(500 \mathrm{MHz}, \mathrm{CDCl}_{3}\right) \delta$ $1.04\left(3 \mathrm{H}, \mathrm{t}, J=7 \mathrm{~Hz}, \mathrm{CH}_{3}\right), 3.04\left(12 \mathrm{H}, \mathrm{s}, \mathrm{NCH}_{3}\right), 4.80(2 \mathrm{H}, \mathrm{q}, J=$ $\left.7 \mathrm{~Hz}, \mathrm{CH}_{2}\right), 6.42(2 \mathrm{H}, \mathrm{dd}, J=2.5 \mathrm{~Hz}, 6 \mathrm{~Hz}, \mathrm{ArH}), 6.76(2 \mathrm{H}, \mathrm{d}, J$ $=2.5 \mathrm{~Hz}, \mathrm{ArH}), 8.27(2 \mathrm{H}, \mathrm{d}, J=6 \mathrm{~Hz}, \mathrm{ArH}) ;{ }^{13} \mathrm{C}-\mathrm{NMR}(125$ $\left.{ }_{80} \mathrm{MHz}, \mathrm{CDCl}_{3}\right) \delta 16.6\left(\mathrm{CH}_{3}\right), 39.2\left(\mathrm{NCH}_{3}\right), 40.7\left(\mathrm{CH}_{2}\right), 104.7$ $(\mathrm{CH}), 105.9(\mathrm{CH}), 110.6(\mathrm{CH}), 136.0(\mathrm{C}), 144.0(\mathrm{CH}), 153.0(\mathrm{C})$, $154.8(\mathrm{C}) ; \mathrm{m} / z\left(\mathrm{ESI}^{+}\right) 336\left([\mathrm{M}+\mathrm{H}]^{+}, 100 \%\right), 337(20), 338(3)$.

\section{EPR measurements:}

${ }_{85}$ Deoxygenated dry DMF (15 mL) was added under a flow of argon to an oven-dried $25 \mathrm{~mL}$ round-bottomed flask containing sodium amalgam (prepared from $50 \mathrm{mg}$ of sodium in $5 \mathrm{~g}$ of mercury) and the donor precursor diiodide salt $(69.7 \mathrm{mg}, 0.113$ mmol, 1 eq.). The deep purple reaction mixture was stirred at 90 room temperature under fast argon flow for $3 \mathrm{~h}$. Three test aliquots of this $0.0075 \mathrm{M}$ solution were transferred into an oven dried syringe needle and the centre of a freshly created stream of this air-sensitive solution was immediately drawn from inside the tip of the syringe needle into a $1 \mathrm{~mm}$ diameter glass capillary 95 (with a sample height of around $5 \mathrm{~cm}$ ) before being sealed at the open end by flame-gun. This was repeated a fourth time until there was great confidence that no oxygen was present in the sample solution (which maintained a deep purple colour). ESR data were then obtained for this sample, which showed a signal 100 with g-factor 2.0035).

To an oven-dried $25 \mathrm{~mL}$ round bottom flask containing diphenylpicrylhydrazyl (DPPH, $44.5 \mathrm{mg}, 0.113 \mathrm{mmol}, 1 \mathrm{eq}$.) was added deoxygenated dry DMF $(15 \mathrm{~mL})$ and a sample of this $1050.0075 \mathrm{M}$ solution was transferred into a $1 \mathrm{~mm}$ capillary in an identical manner to that mentioned above so that a reference ESR signal could be obtained (g-factor 2.0035). Comparison of the signal intensities indicated a concentration of $9 \times 10^{7} \mathrm{M}$, corresponding to $0.012 \mathrm{M}$ conversion of the donor to the radical 110 cation within that solution.

Preparation of $N$-ethyl-2,5-bis-( $N^{\prime}$-methyl-4-dimethylamino2-pyridinium iodide)pyrrole 25:

115 Methyl iodide (12 mL, $192 \mathrm{mmol}, 15$ eq.) was added dropwise to a solution of $\mathrm{N}$-ethyl-2,5-bis-(4-dimethylamino-2-pyridyl)pyrrole 24 (4.30 g, $12.8 \mathrm{mmol}, 1$ eq.) in acetonitrile $(80 \mathrm{~mL})$ was under argon. The solution was refluxed and the suspension formed was left stirring overnight. The suspension was cooled to room 120 temperature, diethyl ether $(100 \mathrm{~mL})$ was added and the solid was filtered via suction and washed with diethyl ether several times to afford N-ethyl-2,5-bis-(N'-methyl-4-dimethylamino-2-pyridinium 
iodide)pyrrole 25 (7.50 g, 95\%) as a light brown powder; m.p. (dec.) $\mathrm{T}>250{ }^{\circ} \mathrm{C}$; [Found: $\left(\mathrm{NSI}^{+}\right)(\mathrm{M}-2 \mathrm{I})^{2+} 182.6281 \mathrm{C}_{22} \mathrm{H}_{31} \mathrm{~N}_{5}$ $(\mathrm{M}-2 \mathrm{I})^{2+}$ requires 182.6284$] ; v_{\max }(\mathrm{KBr}) / \mathrm{cm}^{-1} 2924,1674,1567$, 1382, 1314, 1059; ${ }^{1} \mathrm{H}-\mathrm{NMR}\left(500 \mathrm{MHz}, \mathrm{DMSO}-\mathrm{d}_{6}\right) \delta 0.91(3 \mathrm{H}, \mathrm{t}$, $\left.{ }_{5} J=7 \mathrm{~Hz}, \mathrm{CH}_{3}\right), 3.23\left(12 \mathrm{H}, \mathrm{s}, \mathrm{NCH}_{3}\right), 3.74\left(6 \mathrm{H}, \mathrm{s}, \mathrm{NCH}_{3}\right), 3.82$ $\left(2 \mathrm{H}, \mathrm{bs}, \mathrm{CH}_{2}\right), 6.69(2 \mathrm{H}, \mathrm{s}, \mathrm{ArH}), 7.11(2 \mathrm{H}, \mathrm{d}, J=3 \mathrm{~Hz}, \mathrm{ArH})$, $7.15(2 \mathrm{H}, \mathrm{dd}, J=3 \mathrm{~Hz}, 7.5 \mathrm{~Hz}, \operatorname{ArH}), 8.42(2 \mathrm{H}, \mathrm{d}, J=7.5 \mathrm{~Hz}$, ArH); ${ }^{13} \mathrm{C}-\mathrm{NMR}\left(125 \mathrm{MHz}, \mathrm{DMSO}-\mathrm{d}_{6}\right) \delta 16.7\left(\mathrm{CH}_{3}\right), 40.5$ $\left(\mathrm{NCH}_{3}\right), 41.1\left(\mathrm{CH}_{2}\right), 43.3\left(\mathrm{NCH}_{3}\right), 107.9(\mathrm{CH}), 111.6(\mathrm{CH})$, $10113.7(\mathrm{CH}), 126.4(\mathrm{C}), 144.2(\mathrm{C}), 145.2(\mathrm{CH}), 156.4(\mathrm{C}), \mathrm{m} / \mathrm{z}$ $\left(\mathrm{NSI}^{+}\right) 182\left([\mathrm{M}-2 \mathrm{I}]^{2+}, 100 \%\right), 337(42), 492(29), 651(13)$.

\section{Preparation of $N$-methyl-1-naphthamide 29:}

15 The general procedure for electron transfer reactions was applied to $N$-methoxy- $N$-methyl-1-naphthamide $(116 \mathrm{mg}, 0.54 \mathrm{mmol}, 1$ eq.) using pyrrole salt (500 $\mathrm{mg}, 0.81 \mathrm{mmol}, 1.5 \mathrm{eq}$.). The reaction was stirred at room temperature and the crude material was purified by column chromatography $(5 \%$ EtOAc/DCM) to give ${ }_{20} \mathrm{~N}$-methyl-1-naphthamide $29(102 \mathrm{mg}, 96 \%)$ as a white crystalline solid m. p. $159-161{ }^{\circ} \mathrm{C}$ (lit. ${ }^{43}$ : $\left.159-160{ }^{\circ} \mathrm{C}\right) ;{ }^{1} \mathrm{H}-\mathrm{NMR}(500$ $\left.\mathrm{MHz}, \mathrm{CDCl}_{3}\right) \delta 3.08\left(3 \mathrm{H}, \mathrm{d}, J=4.9 \mathrm{~Hz}, \mathrm{CH}_{3}\right), 6.05(1 \mathrm{H}, \mathrm{bs}, \mathrm{NH})$, 7.42-7.47 (1H, m, ArH), 7.51-7.60 (3H, m, ArH), 7.85-7.92 (2H, m, ArH), 8.29-8.31 (1H, m, ArH); ${ }^{13} \mathrm{C}-\mathrm{NMR}\left(125 \mathrm{MHz}, \mathrm{CDCl}_{3}\right)$ ${ }_{25} \delta 26.8\left(\mathrm{CH}_{3}\right), 124.7(\mathrm{CH}), 124.9(\mathrm{CH}), 125.5(\mathrm{CH}), 126.4(\mathrm{CH})$, $127.1(\mathrm{CH}), 128.3(\mathrm{CH}), 130.1(\mathrm{C}), 130.5(\mathrm{CH}), 133.7(\mathrm{C}), 134.7$ (C), $170.3(\mathrm{C})$.

\section{Preparation of $N$-phenyl- $N$-benzyl-4-methylbenzenesulfon- 30 amide 30:}

An oven-dried flask containing $N$-benzylaniline $(2.01 \mathrm{~g}, 11.0$ mmol, 1 eq.) and $\mathrm{NaH}$ (60\% dispersed in mineral oil, $526 \mathrm{mg}$, 13.2 mmol, 1.2 eq.) under flow of argon, was washed with dry hexane $(3 \times 20 \mathrm{~mL})$ prior to addition of dry THF $(100 \mathrm{~mL})$. To 35 this was added a solution of tosyl chloride $(2.10 \mathrm{~g}, 11.0 \mathrm{mmol}, 1$ eq.) in THF $(30 \mathrm{~mL})$. Solution was stirred at room temperature overnight. THF was removed under reduced pressure and partitioned between EtOAc and $1 \mathrm{M} \mathrm{HCl}(\mathrm{aq})$. The organic phase was washed with $\mathrm{NaHCO}_{3(\mathrm{aq})}(1$ x $100 \mathrm{~mL})$, brine $(1$ x $100 \mathrm{~mL})$ 40 and dried over $\mathrm{Na}_{2} \mathrm{SO}_{4}$. The crude solution was concentrated under reduced pressure and recrystallised in DCM/Hexane to afford $N$-phenyl- $N$-benzyl-4-methylbenzenesulfonamide 30 (3.38 g, $91 \%)$ as a white solid; m.p. $138-140{ }^{\circ} \mathrm{C}\left(\right.$ lit $\left.^{16} .139-140{ }^{\circ} \mathrm{C}\right) ;{ }^{1} \mathrm{H}-$ NMR $\left(500 \mathrm{MHz}, \mathrm{CDCl}_{3}\right) \delta 2.45\left(3 \mathrm{H}, \mathrm{s}, \mathrm{CH}_{3}\right), 4.73\left(2 \mathrm{H}, \mathrm{s}, \mathrm{CH}_{2}\right)$, ${ }_{45}$ 6.98-7.00 (2H, m, ArH), 7.20-7.23 (8H, m, ArH), 7.27-7.29 (2H, $\mathrm{m}, \mathrm{ArH}), 7.55-7.56(2 \mathrm{H}, \mathrm{m}, \mathrm{ArH}) ;{ }^{13} \mathrm{C}-\mathrm{NMR}\left(125 \mathrm{MHz}, \mathrm{CDCl}_{3}\right)$ $\delta 21.2\left(\mathrm{CH}_{3}\right), 54.7\left(\mathrm{CH}_{2}\right), 127.6(\mathrm{CH}), 127.8(\mathrm{CH}), 128.4(\mathrm{CH})$, $128.5(\mathrm{CH}), 128.8(\mathrm{CH}), 129.0(\mathrm{CH}), 129.5(\mathrm{CH}), 135.7(\mathrm{C})$, 136.0 (C), 139.0 (C), 143.5 (C). Data were consistent with those 50 previously published. ${ }^{16}$

\section{Preparation of $\mathrm{N}$-benzylaniline 31:}

The general procedure for electron transfer reactions was applied to $N$-phenyl- $N$-benzyl-4-methylbenzenesulfonamide $\mathbf{3 0}(90.8 \mathrm{mg}$, ${ }_{55} 0.27 \mathrm{mmol}, 1$ eq.) using pyrrole salt 25 (500 $\mathrm{mg}, 0.81 \mathrm{mmol}, 3$ eq.). The reaction was heated to $100{ }^{\circ} \mathrm{C}$ and the crude material was purified by column chromatography $(20 \%$ EtOAc/Pet. Ether) to give $N$-benzylaniline $\mathbf{3 1}$ (33 $\mathrm{mg}, 68 \%$ ) as a white solid; $\mathrm{m}$. p. 35-37 ${ }^{\circ} \mathrm{C}$ (lit. ${ }^{7} 35-38{ }^{\circ} \mathrm{C}$ ); ${ }^{1} \mathrm{H}-\mathrm{NMR}\left(500 \mathrm{MHz}, \mathrm{CDCl}_{3}\right) \delta 4.08$ $60(1 \mathrm{H}, \mathrm{bs}, \mathrm{NH}), 4.35\left(2 \mathrm{H}, \mathrm{s}, \mathrm{CH}_{2}\right), 6.65-6.67(2 \mathrm{H}, \mathrm{m}, \mathrm{ArH}), 6.74$ $(1 \mathrm{H}, \mathrm{t}, J=7 \mathrm{~Hz}, \mathrm{ArH}), 7.12-7.21(2 \mathrm{H}, \mathrm{m}, \mathrm{ArH}), 7.29-7.30(1 \mathrm{H}$, m, ArH), 7.34-7.40 (4H, m, ArH); ${ }^{13} \mathrm{C}-\mathrm{NMR}\left(125 \mathrm{MHz}, \mathrm{CDCl}_{3}\right)$ $\delta 48.7\left(\mathrm{CH}_{2}\right), 112.0(\mathrm{CH}), 118.1(\mathrm{CH}), 128.5(\mathrm{CH}), 128.7(\mathrm{CH})$, $129.1(\mathrm{CH}), 129.7(\mathrm{CH}), 139.8(\mathrm{C}), 148.4(\mathrm{C})$; Data consistent ${ }_{65}$ with those previously published. ${ }^{35}$

\section{Preparation of 1-(toluene-4-sulfonyl)- $1 \boldsymbol{H}$-indole 32:}

An oven-dried flask containing indole (5 g, $42 \mathrm{mmol}, 1 \mathrm{eq}$.$) and$ $\mathrm{NaH}$ (60\% dispersed in mineral oil, $2.05 \mathrm{~g}, 51 \mathrm{mmol}, 1.2$ eq.) 70 under flow of argon, was washed with dry hexane $(3 \times 50 \mathrm{~mL})$ prior to addition of dry THF $(200 \mathrm{~mL})$. To this was added a solution of tosyl chloride $(8.14 \mathrm{~g}, 42 \mathrm{mmol}, 1$ eq.) in THF (50 $\mathrm{mL}$ ). The solution was stirred at room temperature overnight. THF was removed under reduced pressure and partitioned 75 between EtOAc and $1 \mathrm{M} \mathrm{HCl}_{(\mathrm{aq})}$. The organic phase was washed with $\mathrm{NaHCO}_{3(\mathrm{aq})}(1 \times 100 \mathrm{~mL})$, brine $(1 \times 100 \mathrm{~mL})$ and dried over $\mathrm{Na}_{2} \mathrm{SO}_{4}$. The crude solution was concentrated under reduced pressure and recrystallised in DCM/Hexane to afford 1-(toluene4-sulfonyl)-1 $H$-indole 32 (10.9 g, 94\%) as a white solid m.p. 82$8084{ }^{\circ} \mathrm{C}$ (lit. ${ }^{16}: 83-84{ }^{\circ} \mathrm{C}$ ); ${ }^{1} \mathrm{H}-\mathrm{NMR}\left(500 \mathrm{MHz}, \mathrm{DMSO}-\mathrm{d}_{6}\right) \delta 2.29$ $\left(3 \mathrm{H}, \mathrm{s}, \mathrm{CH}_{3}\right), 6.81-6.83$ (1H, m, ArH), 7.22-7.25 (1H, m, ArH), 7.31-7.37 (3H, m, ArH), 7.58-5.60 (1H, m, ArH), 7.77-7.78 $(1 \mathrm{H}$, $\mathrm{m}, \mathrm{ArH}), 7.83-7.85(2 \mathrm{H}, \mathrm{m}, \mathrm{ArH}), 7.91-7.93(1 \mathrm{H}, \mathrm{m}, \mathrm{ArH}) ;{ }^{13} \mathrm{C}-$ NMR (125 MHz, DMSO-d 6$) \delta 20.5\left(\mathrm{CH}_{3}\right), 108.7(\mathrm{CH}), 113.5$ $85(\mathrm{CH}), 120.2(\mathrm{CH}), 123.5(\mathrm{CH}), 125.2(\mathrm{CH}), 126.3(\mathrm{CH}), 130.6$ (CH), $131.0(\mathrm{C}), 134.8(\mathrm{C}), 135.1(\mathrm{C}), 145.1(\mathrm{C})$.

\section{Preparation of $\mathbf{1 H}$-indole 33:}

The general procedure for electron transfer reactions was applied 90 to 1 -(toluene-4-sulfonyl)- $1 H$-indole 32 ( $73 \mathrm{mg}, 0.27 \mathrm{mmol}, 1$ eq.) using pyrrole salt 25 (500 $\mathrm{mg}, 0.81 \mathrm{mmol}, 3$ eq.). The reaction was heated to $100{ }^{\circ} \mathrm{C}$ and the crude material was purified by column chromatography $(20 \%$ EtOAc/Pet. ether) to give $1 \mathrm{H}$ indole 33 (27 mg, 87\%) as a white solid; m. p. $52-53{ }^{\circ} \mathrm{C}$ (lit. ${ }^{16} 51-$ $\left.{ }_{95} 54{ }^{\circ} \mathrm{C}\right)$; ${ }^{1} \mathrm{H}-\mathrm{NMR}\left(500 \mathrm{MHz}, \mathrm{CDCl}_{3}\right) \delta$ 6.64-6.65 (1H, m, ArH), 7.19-7.31 (3H, m, ArH), 7.41-7.43 (1H, m, ArH), 7.74-7.76 (1H, $\mathrm{m}, \mathrm{ArH}), 8.01(1 \mathrm{H}, \mathrm{bs}, \mathrm{NH}) ;{ }^{13} \mathrm{C}-\mathrm{NMR}\left(125 \mathrm{MHz}, \mathrm{CDCl}_{3}\right) \delta$ $102.6(\mathrm{CH}), 111.3(\mathrm{CH}), 119.9(\mathrm{CH}), 120.8(\mathrm{CH}), 122.1(\mathrm{CH})$, $124.3(\mathrm{CH}), 127.9(\mathrm{C}), 135.8(\mathrm{C})$.

100

Preparation of $N, N^{\prime}, N^{\prime}$-tris( $p$-toluenesulfonyl)tryptamine 34: To a solution of tryptamine $(1.00 \mathrm{~g}, 6.24 \mathrm{mmol}, 1 \mathrm{eq}$.) in dry THF $(100 \mathrm{~mL})$ was added $\mathrm{NaH}(60 \%$ mineral oil, $1.25 \mathrm{~g}, 31.2 \mathrm{mmol}, 5$ eq.) and light brown suspension was stirred for $10 \mathrm{~min}$. To this 105 was added a solution of tosyl chloride ( $4.76 \mathrm{~g}, 25.0 \mathrm{mmol}, 4$ eq.) in dry THF $(50 \mathrm{~mL})$ via cannula and suspension was stirred for $18 \mathrm{~h}$ under argon. Reaction was concentrated under reduced pressure and partitioned between EtOAc $(100 \mathrm{~mL})$ and $2 \mathrm{M}$ $\mathrm{NaOH}_{(\mathrm{aq})}(50 \mathrm{~mL})$. Organic layer was washed with brine $(50 \mathrm{~mL})$ 110 and dried over $\mathrm{Na}_{2} \mathrm{SO}_{4}$. The crude solution was concentrated under reduced pressure and purified by column chromatography (10\% EtOAc/hexane) to give $N, N^{\prime}, N^{\prime}$-tris(toluenesulfonyl)tryptamine $34(1.53 \mathrm{~g}, 37 \%)$ as a pink foam; [Found: (NSI) ${ }^{+}$ $\left(\mathrm{M}+\mathrm{NH}_{4}\right)^{+} \quad 640.1600, \quad \mathrm{C}_{31} \mathrm{H}_{34} \mathrm{~N}_{3} \mathrm{O}_{6} \mathrm{~S}_{3} \quad\left(\mathrm{M}+\mathrm{NH}_{4}\right)^{+}$requires 115 640.1604]; $v_{\max }(\mathrm{KBr}) / \mathrm{cm}^{-1} 3387,2941,2074,1635,1566,1526$, 1448, 1390, 1310, 1252, 1206, 1163, 1118, 1050, 924, 811, 624; ${ }^{1} \mathrm{H}-\mathrm{NMR}\left(500 \mathrm{MHz}, \mathrm{CDCl}_{3}\right) \delta 2.36\left(3 \mathrm{H}, \mathrm{s}, \mathrm{CH}_{3}\right), 2.47(6 \mathrm{H}, \mathrm{s}$, $\left.\mathrm{CH}_{3}\right), 3.09-3.13\left(2 \mathrm{H}, \mathrm{m}, \mathrm{CH}_{2}\right), 3.88-3.92\left(2 \mathrm{H}, \mathrm{m}, \mathrm{NCH}_{2}\right), 7.23-$ $7.35(9 \mathrm{H}, \mathrm{m}, \mathrm{ArH}), 7.60(1 \mathrm{H}, \mathrm{d}, J=8.2 \mathrm{~Hz}, \mathrm{ArH}), 7.77(4 \mathrm{H}, \mathrm{d}, J$ $\left.{ }_{120}=8.4 \mathrm{~Hz}, \mathrm{ArH}\right), 7.91(2 \mathrm{H}, \mathrm{d}, J=8.4 \mathrm{~Hz}, \mathrm{ArH}), 7.98(1 \mathrm{H}, \mathrm{d}, J=$ $8.2 \mathrm{~Hz}, \mathrm{ArH}) ;{ }^{13} \mathrm{C}-\mathrm{NMR}\left(125 \mathrm{MHz}, \mathrm{CDCl}_{3}\right) \delta 21.1\left(\mathrm{CH}_{3}\right), 21.2$ $\left(\mathrm{CH}_{3}\right), 26.1\left(\mathrm{CH}_{2}\right), 48.6\left(\mathrm{NCH}_{2}\right), 113.7(\mathrm{CH}), 118.2(\mathrm{C}), 119.5$ 
$(\mathrm{CH}), 123.3(\mathrm{CH}), 123.8(\mathrm{CH}), 124.9(\mathrm{CH}), 126.8(\mathrm{CH}), 128.2$ $(\mathrm{CH}), 129.8(\mathrm{CH}), 129.9(\mathrm{CH}), 130.4(\mathrm{C}), 135.1(\mathrm{C}), 135.4(\mathrm{C})$, 136.9 (C), 144.9 (C), 145.1 (C). $\mathrm{m} / z(\mathrm{ESI}+) 640[(\mathrm{M}+\mathrm{NH} 4)+$, $100 \%]$.

Preparation of 3-(2-( $p$-toluenesulfonylamido)ethyl)indole 35: The general procedure for electron transfer reactions was applied to $N, N, N$-tris(toluenesulfonyl)tryptamine $34(200 \mathrm{mg}, 0.30 \mathrm{mmol}$, 1 eq.) using pyrrole salt 25 (748 mg, $1.20 \mathrm{mmol}, 4$ eq.). The 10 reaction was heated to $100{ }^{\circ} \mathrm{C}$ and the crude material was purified by column chromatography (30\% EtOAc/hexane) to give 3-(2( $p$-toluenesulfonylamido)ethyl)indole $35(89 \mathrm{mg}, 94 \%)$ as a clear oil; ${ }^{1} \mathrm{H}-\mathrm{NMR}\left(500 \mathrm{MHz}, \mathrm{CDCl}_{3}\right) \delta 2.41\left(3 \mathrm{H}, \mathrm{s}, \mathrm{CH}_{3}\right), 2.94(2 \mathrm{H}, \mathrm{t}$, $\left.J=6.4 \mathrm{~Hz}, \mathrm{CH}_{2}\right), 3.28\left(2 \mathrm{H}, \mathrm{q}, J=6.4 \mathrm{~Hz}, \mathrm{CH}_{2}\right), 4.50(1 \mathrm{H}, \mathrm{t}, J=$ $156.4 \mathrm{~Hz}, \mathrm{NH}), 6.97(1 \mathrm{H}, \mathrm{ArH}), 7.06(1 \mathrm{H}, \mathrm{t}, J=8 \mathrm{~Hz}, \mathrm{ArH}), 7.18-$ $7.23(3 \mathrm{H}, \mathrm{m}, \mathrm{ArH}), 7.38(1 \mathrm{H}, \mathrm{d}, J=8 \mathrm{~Hz}, \mathrm{ArH}), 7.43(1 \mathrm{H}, \mathrm{d}, J=$ $8 \mathrm{~Hz}, \mathrm{ArH}), 7.64(2 \mathrm{H}, \mathrm{d}, J=8 \mathrm{~Hz}, \mathrm{ArH}), 8.09$ (1H, bs, ArNH); ${ }^{13} \mathrm{C}-\mathrm{NMR}\left(125 \mathrm{MHz}, \mathrm{CDCl}_{3}\right) \delta 21.5\left(\mathrm{CH}_{3}\right), 25.5\left(\mathrm{CH}_{2}\right), 43.1$ $\left(\mathrm{NCH}_{2}\right), 111.3(\mathrm{CH}), 111.6(\mathrm{C}), 118.5(\mathrm{CH}), 119.5(\mathrm{CH}), 122.3$ $20(\mathrm{CH}), 122.4(\mathrm{CH}), 126.9(\mathrm{C}), 127.0(\mathrm{CH}), 129.6(\mathrm{CH}), 136.4(\mathrm{C})$, 136.8 (C), 143.3 (C). Data were consistent with those published in literature. ${ }^{13}$

Acknowledgements. We thank Professor John C. Walton and 25 Dr. Michael J. Corr for EPR measurements (St. Andrews University), and we thank University of Strathclyde, Scottish Funding Council and BAE Systems for a SPIRIT studentship to HSF. Mass spectrometry data were acquired at the EPSRC UK National Mass Spectrometry Facility at Swansea University.

\section{${ }_{30}$ Notes and references}

${ }^{a}$ WestCHEM, Dept. of Pure and Applied Chemistry, 295 Cathedral Street, Glasgow G1 1XL, United Kingdom. E-mail: John.murphy@strath.ac.uk

${ }^{\mathrm{b}}$ WestCHEM, School of Chemistry, University of Glasgow, Joseph Black Building, University Avenue, Glasgow, G12 8QQ, United Kingdom.

$\dagger$ Electronic Supplementary Information (ESI) available: computational coordinates and NMR spectra are provided. See DOI: 10.1039/b000000x/

1 A. J. Birch, Q. Rev. Chem. Soc., 1950, 4, 69-93.

40 2. K. Rühlmann, Synthesis, 1971, 236-253.

3. K. T. Finley, Chem. Rev., 1964, 64, 573-589.

4. D. V. Yandulov and R. R. Schrock, Science, 2003, 301, 76-78.

5. N. G. Connelly and W. E. Geiger, Chem. Rev., 1996, 96, 877-910.

6. J. L. Segura and N. Martin, Angew. Chem. Int. Ed., 2001, 40, 13721409.

7. C. Burkholder, W. R. Dolbier and M. Medebielle, J. Org. Chem., 1998, 63, 5385-5394

8. T. P. Vaid, J. Am. Chem. Soc., 2011, 133, 15838-15841.

9. D. Emeljanenko, A. Peters, V. Vitske, E. Kaifer and H.-J. Himmel,

$50 \quad$ Eur. J. Inorg. Chem., 2010, 4783-4789.

10. J. R. Ames, M. A. Houghtaling, D. L. Terrian and T. P. Mitchell, Can. J. Chem., 1997, 75, 28.

11. W. W. Porter, T. P. Vaid and A. L. Rheingold, J. Am. Chem. Soc., 2005, 127, 16559-16566.

55 12. J. Murphy, S. Z. Zhou, D. Thomson, F. Schoenebeck, M. Mahesh, S. Park, T. Tuttle and L. Berlouis, Angew. Chem. Int. Ed., 2007, 46, 5178-5183.

13. Z. Han, T. P. Vaid and A. L. Rheingold, J. Org. Chem., 2008, 73, 445-450.

6014 . J. A. Murphy, J. Garnier, S. R. Park, F. Schoenebeck, S. Z. Zhou and A. T. Turner, Org. Lett., 2008, 10, 1227-1230.

15. J. A. Murphy, T. A. Khan, S. Z. Zhou, D. W. Thomson and M. Mahesh, Angew. Chem. Int. Ed., 2005, 44, 1356-1360.
16. F. Schoenebeck, J. A. Murphy, S. Z. Zhou, Y. Uenoyama, Y. Miclo and T. Tuttle, J. Am. Chem. Soc., 2007, 129, 13368-13369.

17. S. P. Y. Cutulic, J. A. Murphy, H. Farwaha, S.-Z. Zhou and E. Chrystal, Synlett, 2008, 2132-2136.

18. S. P. Y. Cutulic, N. J. Findlay, S.-Z. Zhou, E. J. T. Chrystal and J. A. Murphy, J. Org. Chem., 2009, 74, 8713-8718.

70 19. J. Garnier, A. R. Kennedy, L. E. A. Berlouis, A. T. Turner and J. A. Murphy, Beilstein J. Org. Chem., 2010, 6, 73.

20. Advanced Inorganic Chemistry, F. A. Cotton, G. Wilkinson, $4^{\text {th }}$ Edition, J. Wiley \& Sons 1980, Oxford.

21. Z. Shi, V. Goulle and R. P. Thummel, Tetrahedron Lett., 1996, 37, 2357-2360.

22. T. A. Taton and P. Chen, Angew. Chem. Int. Ed., 1996, 35, 10111013.

23. R. W. Alder, M. E. Blake, L. Chaker, J. N. Harvey, F. Paolini and J. Schutz, Angew. Chem. Int. Ed. 2004, 43, 5896-5911.

80 24. P. I. Jolly, S. Zhou, D. W. Thomson, J. Garnier, J. A. Parkinson, T. Tuttle and J. A. Murphy, Chem. Sci., 2012, 3, 1675-1679.

25. M. J. Corr, K. F. Gibson, A. R. Kennedy and J. A. Murphy, J. Am. Chem. Soc., 2009, 131, 9174-9175.

26. M. J. Corr, M. D. Roydhouse, K. F. Gibson, S.-Z. Zhou, A. R.

85 Kennedy and J. A. Murphy, J. Am. Chem. Soc., 2009, 131, 1798017985.

27. B. Bolto, R. McNeill and D. Weiss, Aust. J. Chem., 1963, 16, 10901103 .

28. A. Watanabe, S. Murakami, K. Mori and Y. Kashiwaba, Macromolecules, 1989, 22, 4231-4235.

29. C. L. Gaupp, K. Zong, P. Schottland, B. C. Thompson, C. A. Thomas and J. R. Reynolds, Macromolecules, 2000, 33, 1132-1133.

30. C. C. Bof Bufon, T. Heinzel, P. Espindola and J. Heinze, J. Phys. Chem. B., 2009, 114, 714-718.

95 31. J. W. Ciszek, Z. K. Keane, L. Cheng, M. P. Stewart, L. H. Yu, D Natelson and J. M. Tour, J. Am. Chem. Soc., 2006, 128, 3179-3189.

32. P. Gros, S. Choppin, J. Mathieu and Y. Fort, J. Org. Chem., 2001, 67, 234-237.

33. S. V. Kessar, P. Singh, K. N. Singh and M. Dutt, J. Chem. Soc., Chem. Commun., 1991, 570-571.

34. T. Sammakia and T. B. Hurley, J. Org. Chem., 1999, 64, 4652-4664.

35. E. Vedejs and X. Chen, J. Am. Chem. Soc., 1996, 118, 1809-1810.

36. Gaussian 09, Revision A.02, M. J. Frisch, G. W. Trucks, H. B. Schlegel, G. E. Scuseria, M. A. Robb, J. R. Cheeseman, G. Scalmani,

105 V. Barone, B. Mennucci, G. A. Petersson, H. Nakatsuji, M. Caricato, X. Li, H. P. Hratchian, A. F. Izmaylov, J. Bloino, G. Zheng, J. L. Sonnenberg, M. Hada, M. Ehara, K. Toyota, R. Fukuda, J. Hasegawa, M. Ishida, T. Nakajima, Y. Honda, O. Kitao, H. Nakai, T. Vreven, J. A. Montgomery, Jr., J. E. Peralta, F. Ogliaro, M. Bearpark, J. J.

110 Heyd, E. Brothers, K. N. Kudin, V. N. Staroverov, R. Kobayashi, J. Normand, K. Raghavachari, A. Rendell, J. C. Burant, S. S. Iyengar, J. Tomasi, M. Cossi, N. Rega, J. M. Millam, M. Klene, J. E. Knox, J. B. Cross, V. Bakken, C. Adamo, J. Jaramillo, R. Gomperts, R. E. Stratmann, O. Yazyev, A. J. Austin, R. Cammi, C. Pomelli, J. W. Ochterski, R. L. Martin, K. Morokuma, V. G. Zakrzewski, G. A. Voth, P. Salvador, J. J. Dannenberg, S. Dapprich, A. D. Daniels, Ö. Farkas, J. B. Foresman, J. V. Ortiz, J. Cioslowski and D. J.Fox, Gaussian, Inc., Wallingford CT, 2009.

37 Y. Zhao, N. E. Schultz and D. G. Truhlar, J. Chem. Theory Comput.2006, 2, 364-382.

38. R. A. Kendall, T. H. Dunning and R. J. Harrison, R. J. J. Chem. Phys. 1992, 96, 6796-6806

39 S. Miertuš, E. Scrocco and J. Tomasi, J. J. Chem. Phys. 1981, 55, $117-$ 129.

125 40. K. Uchiyama, Y. Hayashi and K. Narasaka, Tetrahedron 1999, 55, 8915-8930

41. S. V. Kessar, P. Singh, K. N. Singh and M. Dutt, J. Chem. Soc., Chem. Commun. 1991, 570-571

42 D. Cuperly, P. Gros, Y. Fort, J. Org. Chem. 2001, 67, 238-241.

130 43. Y. Jo, J. Ju, J. Choe, K. H. Song and S. Lee, J. Org. Chem. 2009, 74, 6358-6361

44. D. L. Priebbenow, L. C. Henderson, F. M. Pfeffer and S. G. Stewart, S. G., J. Org. Chem 2010, 75, 1787-1790

135 
Cite this: DOI: 10.1039/coxxooooox

www.rsc.org/xxxxxx

ARTICLE TYPE 